\title{
REFLEXÓES SOBRE A POSSIBILIDADE DE PAGAMENTO DOS HONORÁRIOS ADVOCATÍCIOS À DEFENSORIA PÚBLICA QUANDO LITIGA CONTRA O ENTE FEDERATIVO AO QUAL É VINCULADA (TEMA 1002 - REPERCUSSÃO GERAL - STF)
}

REFLECTIONS ON THE POSSIBILITY OF PAYING ATTORNEY FEES TO THE PUBLIC ATTORNEY OFFICE WHEN LITIGATING AGAINST THE PUBLIC ENTITY TO WHICH IT IS BOUND ((THEME 1.002 - GENERAL REPERCUSSION - STF)

Graziela Martins Palhares de Melo

Mestre em Direito pela Universidade de Brasilia Assessora Jurídical Analista Processual do Ministério Público Federal - MPF grazielapalhares@gmail.com

\section{RESUMO}

O tema abordado no presente trabalho guardou relação com a questão constitucional suscitada no RE 1.140.005 - RG (Tema 1002), qual seja, "saber se a proibição ao recebimento de honorários advocatícios pela Defensoria Pública, quando representa litigante vencedor em demanda ajuizada contra o ente ao qual é vinculada, viola a sua autonomia funcional, administrativa e institucional". O objetivo central da pesquisa consistiu em perquirir a viabilidade de a Defensoria Pública receber a verba honorária nas causas em que litiga contra o ente público ao qual se vincula, considerando que a jurisprudência dominante do Superior Tribunal de Justiça, expressa na Súmula 421/STJ, não admite tal possibilidade. Para tanto, foi adotada como metodologia de pesquisa a revisão normativa e doutrinária, bem como a análise jurisprudencial sobre os aspectos sensíveis da matéria. Os objetivos específicos do trabalho foram: revelar o status constitucional atual da Defensoria Pública; identificar o cabimento dos honorários advocatícios à Defensoria Pública, sob os aspectos normativo e jurisprudencial; apontar os fundamentos pelos quais o pagamento dos honorários advocatícios à Defensoria Pública deve ser admitido.

Palavras-chave: Defensoria Pública. Autonomia institucional. Ente público vinculado. Honorários advocatícios. Tema 1002 - STF.

\section{ABSTRACT}

The subject addressed in the present study relates to the constitutional issue raised in the Supreme Court's binding precedent number 1002, RE 1.140.005, namely, "whether the prohibition on the receipt of attorney fees by the Public Attorney Office when it represents the winning party on demand brought against the branch to which he/she is linked, violates its functional, administrative and institutional autonomy". The main 
objective of the research was to assess the viability of the Public Attorney's Office to be entitled the collection of the fee in the cases in which it disputes against the public entity to which it is bound, considering that the Superior Court of Justice does not admit such possibility through its binding case summary number 421 . To this end, the research methodology applied was the normative and doctrinal review, as well as the case law analysis on the sensitive aspects of the subject. The specific objectives of the work were: to reveal the current constitutional status of the Public Attorney's Office; identify the appropriateness of attorney's fees to the Public Attorney's Office under the normative and case law aspects; indicate the grounds on which the payment of attorney's fees to the Public Attorney's Office should be admitted.

Keywords: Public Attorney's Office. Institutional autonomy. Entity linked public. Attorney`s fee. Supreme Court's binding precedent number 1002.

\section{SUMÁRIO}

INTRODUCCÃO 1. DO STATUS CONSTITUCIONAL DA DEFENSORIA PÚBLICA 2. DOS HONORÁRIOS ADVOCATÍCIOS DEVIDOS À DEFENSORIA PÚBLICA - ASPECTOS NORMATIVO E JURISPRUDENCIAL 3. DA ADMISSIBILIDADE DO PAGAMENTO DE HONORÁRIOS ADVOCATÍCIOS À DEFENSORIA PÚBLICA QUANDO LITIGA CONTRA O ENTE AO QUAL É VINCULADA CONSIDERAÇÓES FINAIS

Data de submissão: 21/01/2020

Data de aceitação: 21/05/2020

\section{INTRODUÇÃO}

O Supremo Tribunal Federal reconheceu, em 4/8/2018, a existência de repercussão geral da seguinte questão constitucional suscitada no Leading Case RE 1.140.005 RG (Tema 1002): "saber se a proibição ao recebimento de honorários advocatícios pela Defensoria Pública, quando representa litigante vencedor em demanda ajuizada contra o ente ao qual é vinculada, viola a sua autonomia funcional, administrativa e institucional".

A controvérsia agitada no referido Case é extremamente relevante não apenas para a Instituição, mas para toda a sociedade brasileira, dado que eventual reconhecimento no sentido de serem devidas as verbas honorárias a favor da Defensoria Pública terá o condão de dotá-la de recursos financeiros, que hoje, em razão de sua limitação, a precariza e a impede de bem desempenhar seu mister constitucional.

Sendo, pois, manifesta a relevância do tema a ser definido pela Corte Suprema, o presente trabalho tem por objetivo perquirir acerca da possibilidade de pagamento de honorários advocatícios à Defensoria Pública quando litiga contra o ente ao qual se vincula, tal como delimitado no RE 1.140.005 RG (Tema 1002). 
Para responder a essa questão, de reconhecida repercussão geral, realizaremos um levantamento normativo, jurisprudencial e doutrinário acerca dos principais aspectos que envolvem a matéria.

Sendo assim, na primeira parte do trabalho, traçaremos o status constitucional da Defensoria Pública, visando identificar o perfil e as atuais prerrogativas gozadas pela Instituição, a partir dos diplomas legais regentes, da jurisprudência dos Tribunais Superiores e da doutrina selecionada.

Na segunda parte, analisaremos a legalidade do pagamento dos honorários advocatícios à Defensoria Pública, bem como apuraremos o posicionamento atual do Supremo Tribunal Federal e do Superior Tribunal de Justiça acerca da matéria.

Na terceira parte, infirmaremos os fundamentos contrários ao pagamento dos honorários advocatícios à Defensoria Pública que embasam a Súmula 421/STJ e demonstraremos as razóes pelas quais os mesmos não merecem subsistir.

Por derradeiro, com base na argumentação exposta no trabalho, concluiremos que a questão constitucional objeto do RE 1.140.005 RG (Tema 1002) deve ser respondida afirmativamente, de modo a estabelecer-se a seguinte tese: a proibição ao recebimento de honorários advocatícios pela Defensoria Pública, quando representa litigante vencedor em demanda ajuizada contra o ente ao qual é vinculada, viola a sua autonomia funcional, administrativa e institucional.

\section{DO STATUS CONSTITUCIONAL DA DEFENSORIA PÚBLICA}

A Constituição da República Federativa do Brasil de 1988, dando concretude à garantia de acesso à Justiça (art. 50, XXXV, da $\mathrm{CRFB} / 88^{1}$ ) e ao dever do Estado de prestar assistência jurídica integral aos necessitados (art. 5ㅇ, LXXIV, CRFB ${ }^{2}$ ), alçou a Defensoria Pública à condição de instituição essencial à função jurisdicional do Estado, consoante atesta a redação original do artigo 134: "A Defensoria Pública é instituição essencial à função jurisdicional do Estado, incumbindo-lhe a orientação jurídica e a defesa, em todos os graus, dos necessitados, na forma do art. 5, LXXIV".

O destaque constitucional aludido afigura-se plenamente justificável pois, como bem observa Nelson Nery Júnior ${ }^{3}$, ante a desigualdade social reinante no Brasil, seria inócua a previsão normativa conferindo direitos materiais e processuais sem o oferecimento da assistência jurídica gratuita àqueles que não têm condiçôes financeiras de arcar com os custos correspondentes. De sorte que a efetividade da própria Constituição guarda estreita

1 BRASIL. [Constituição (1988)]. Constituição da República Federativa do Brasil de 1988. Art. 5º, XXXV - a lei não excluirá da apreciação do Poder Judiciário lesão ou ameaça a direito.

2 BRASIL. [Constituição (1988)]. Constituição da República Federativa do Brasil de 1988. Art. 5º, LXXIV - o Estado prestará assistência jurídica integral e gratuita aos que comprovarem insuficiência de recursos.

3 NERY JÚNIOR, Nelson. Direito constitucional brasileiro: curso completo. , 2019. 
ligação com a gratuidade do acesso à Justiça, consoante elucida o referido autor ${ }^{4}$ :

[...] A Defensoria é instituiçáo essencial à função jurisdicional do Estado. Esse é o status que lhe é garantido pelo CF 134. Afinal, é a Defensoria que assegura o ideal de justiça plena. A sua inexistência ou ineficácia pode alterar o próprio papel do Judiciário, transformando-o em propagador de uma insuportável desigualdade entre os indivíduos, em termos de jurisdição.

Não é exagero dizer que a Defensoria Pública constitui um verdadeiro pilar do acesso à justiça, porquanto combate um de seus inimigos mais perniciosos: a hipossuficiência socioeconômica que assola a maioria dos brasileiros e os impede de contratar serviços advocatícios no mercado.

Nessa linha, o Supremo Tribunal Federal muito tem contribuído para o fortalecimento do mister constitucional exercido pela Defensoria Pública, ao reconhecer a relevância da Instituição na ordem jurídica brasileira, tal como explicita, dentre outras, a ementa do acórdáo proferido nos autos da ADI 2903/PB5 .

Destarte, contando com o devido respaldo Constitucional, a Defensoria Pública tem se revelado, cada vez mais, indispensável instrumento a serviço do regime democrático ao contribuir, precipuamente, para a concretização dos direitos e liberdades titularizados pelos mais desfavorecidos economica e socialmente.

O advento das Emendas Constitucionais no ${ }^{\circ} 45 / 2004^{6}, 74 / 2013^{7}$ e 80/2014 ${ }^{8}$ corroboram tal assertiva, na medida em que, conferindo novos e relevantes contornos à Instituiçấo, alteraram-lhe o perfil, nos termos delineados pela atual redação do artigo 134 da $\mathrm{CRFB}^{9}$, verbis:

Art. 134. A Defensoria Pública é instituição permanente, essencial à função jurisdicional do Estado, incumbindo-lhe, como expressão e instrumento do regime democrático, fundamentalmente, a orientação jurídica, a promoção dos direitos humanos e a defesa, em todos os graus, judicial e extrajudicial, dos direitos individuais e coletivos, de forma integral e gratuita, aos necessitados, na forma do inciso

\footnotetext{
$4 \quad$ Ibid.

5 BRASIL. Supremo Tribunal Federal. Açáo Direta de Inconstitucionalidade (ADI) 2903, Relator(a): Min. CELSO DE MELLO, Tribunal Pleno, julgado em 01/12/2005, DJe-177 DIVULG 18-09-2008 PUBLIC 19-09-2008 EMENT VOL-02333-01 PP-00064 RTJ VOL-00206-01 PP-00134.

6 BRASIL. [Constituição (1988)]. Emenda Constitucional n. 45, de 30 de dezembro de 2004. Altera dispositivos dos arts. 5०, 36, 52, 92, 93, 95, 98, 99, 102, 103, 104, 105, 107, 109, 111, 112, 114, 115, 125, 126, 127, 128, 129, 134 e 168 da Constituição Federal, e acrescenta os arts. 103-A, 103B, 111-A e 130-A, e dá outras providências.

7 BRASIL. [Constituição (1988)]. Emenda Constitucional n. 74, de 6 de agosto de 2013. Altera o art. 134 da Constituição Federal.

8 BRASIL. [Constituição (1988)]. Emenda Constitucional n. 80, de 4 de junho de 2014. Altera o art. 134 da Constituição Federal.

9 BRASIL. [Constituição (1988)]. Constituição da República Federativa do Brasil de 1988. Art. 134 A Defensoria Pública é instituição permanente, essencial à função jurisdicional do Estado[...].
} 
LXXIV do art. $5^{\circ}$ desta Constituição Federal. (Redação dada pela Emenda Constitucional no 80, de 2014)

$\$ 1^{\circ}$ Lei complementar organizará a Defensoria Pública da União e do Distrito Federal e dos Territórios e prescreverá normas gerais para sua organizaçáo nos Estados, em cargos de carreira, providos, na classe inicial, mediante concurso público de provas e títulos, assegurada a seus integrantes a garantia da inamovibilidade e vedado o exercício da advocacia fora das atribuiçôes institucionais. (Renumerado do parágrafo único pela Emenda Constitucional n. 45, de 2004)

$\$ 2$ ò̀s Defensorias Públicas Estaduais são asseguradas autonomia funcional e administrativa e a iniciativa de sua proposta orçamentária dentro dos limites estabelecidos na lei de diretrizes orçamentárias e subordinação ao disposto no art. $99, \$ 2^{\circ}$. (Incluído pela Emenda Constitucional n. 45, de 2004)

$\$ 3^{\circ}$ Aplica-se o disposto no $\$ 2^{\circ}$ às Defensorias Públicas da União e do Distrito Federal (Incluído pela Emenda Constitucional n. 74, de 2013)

$\$ 4$ o São princípios institucionais da Defensoria Pública a unidade, a indivisibilidade e a independência funcional, aplicando-se também, no que couber, o disposto no art. 93 e no inciso II do art. 96 desta Constituição Federal. (Incluído pela Emenda Constitucional n. 80, de 2014)

Imperioso destacar o teor da Emenda Constitucional n. 45/2004, que conferiu às Defensorias Públicas Estaduais autonomia funcional e administrativa, além de iniciativa própria para a elaboração das respectivas propostas orçamentárias, observados os limites estabelecidos na lei de diretrizes orçamentárias e ao disposto no art. $99, \$ 2^{\circ}$, da $\mathrm{CRFB}^{10}$.

No âmbito Federal, tais prerrogativas institucionais foram estendidas expressamente à Defensoria Pública da União, por meio da Emenda Constitucional n. 74/2013. E, no tocante ao Distrito Federal, a Emenda Constitucional 69/2012 ${ }^{11}$ alterou os artigos 21, 22 e 48 da Constituição Federal para transferir da União para o Distrito Federal as atribuiçóes de organizar e manter a respectiva Defensoria Pública.

Merece relevo, mais uma vez, o protagonismo exercido pelo Supremo Tribunal Federal ao reconhecer a eficácia plena e a aplicabilidade imediata das prerrogativas conferidas pela Emenda Constitucional n. 45/04, bem como o caráter autônomo da Instituição, tal como, por exemplo, quando declarou a inconstitucionalidade de normas estaduais que

10 BRASIL. [Constituição (1988)]. Constituição da República Federativa do Brasil de 1988. Art. 99. Ao Poder Judiciário é assegurada autonomia administrativa e financeira. [...] $\$ 2^{\circ} \mathrm{O}$ encaminhamento da proposta, ouvidos os outros tribunais interessados, compete: I - no âmbito da União, aos Presidentes do Supremo Tribunal Federal e dos Tribunais Superiores, com a aprovação dos respectivos tribunais; II - no âmbito dos Estados e no do Distrito Federal e Territórios, aos Presidentes dos Tribunais de Justiça, com a aprovação dos respectivos tribunais.

11 BRASIL. [Constituição (1988)]. Emenda Constitucional n. 69, de 29 de março de 2012. Altera os arts. 21, 22 e 48 da Constituição Federal, para transferir da União para o Distrito Federal as atribuiçóes de organizar e manter a Defensoria Pública do Distrito Federal. 
vinculassem a Defensoria Pública às Secretarias estaduais, ou a quaisquer outros poderes, sob o fundamento de que tal sujeição "impede o pleno exercício de suas funções institucionais, dentre as quais se inclui a possibilidade de, com vistas a garantir os direitos dos cidadão, agir com liberdade contra o próprio Poder Público"1213.

Significativas, outrossim, foram as conquistas proporcionadas pela Emenda Constitucional n. 80/2014, em prol do empoderamento da Defensoria Pública, pois, além de prever a presença da Instituição para todas a unidades jurisdicionais no prazo máximo de oito $\operatorname{anos}^{14}$; conferiu tratamento individual no rol das funçóes essenciais à Justiça, destacando-a da advocacia; ampliou o conceito e o espectro de atuação; tornou explícitos os princípios institucionais da unidade, indivisibilidade e independência funcional e assegurou a aplicação, no que couber, das prerrogativas asseguradas ao Poder Judiciário nos artigos 93 e 96, II, da Constituição Federal, dentre elas, a competência para a propositura de leis que tratam da criação e extinção de cargos no âmbito que lhe é próprio, bem como das respectivas remuneraçóes.

Paralelamente às mudanças constitucionais retrodelineadas, urge destacar o advento da Lei Complementar $n^{\circ} 132$, de 7 de outubro de $2009^{15}$, que alterou significativamente a Lei Orgânica Nacional da Defensoria Pública (Lei Complementar no 80/1994), notadamente no que diz respeito à ampliação da autonomia a Defensoria Pública, consoante explicita Victor Hugo Siqueira de Assis ${ }^{16}$, verbis:

[...] A Lei Complementar no 132/2009 praticamente refundou a De-

12 BRASIL. Supremo Tribunal Federal. Açáo Direta de Inconstitucionalidade (ADI) 3965, Relator(a): Min. CÁRMEN LÚCIA, Tribunal Pleno, julgado em 07/03/2012, ACÓRDÃO ELETRÔNICO DJe-065 DIVULG 29-03-2012 PUBLIC 30-03-2012 REVJMG v. 63, n. 200, 2012, p. 351-355.

13 Nesse diapasão: Supremo Tribunal Federal. Açáo Direta de Inconstitucionalidade (ADI) 3569, Relator(a): Min. SEPÚLVEDA PERTENCE, Tribunal Pleno, julgado em 02/04/2007, DJe-013 DIVULG 10-05-2007 PUBLIC 11-05-2007 DJ 11-05-2007 PP-00047 EMENT VOL-02275-01 PP-00160 LEXSTF v. 29, n. 342, 2007, p. 96-105. Disponível em: http://redir.stf.jus.br/paginadorpub/paginador. jsp?docTP=AC\&docID=452004 . Acesso em: 25 nov. 2019; Açáo Direta de Inconstitucionalidade (ADI) 4056, Relator(a): Min. RICARDO LEWANDOWSKI, Tribunal Pleno, julgado em 07/03/2012, ACÓRDÃO ELETRÔNICO DJe-150 DIVULG 31-07-2012 PUBLIC 01-08-2012). Disponível em: http://redir.stf.jus.br/paginadorpub/paginador.jsp?docTP=TP\&docID $=2455183$. Acesso em: 25 nov. 2019; Açáo Direta de Inconstitucionalidade (ADI) 3965, Relator(a): Min. CÁRMEN LÚCIA, Tribunal Pleno, julgado em 07/03/2012, ACÓRDÃO ELETRÔNICO DJe-065 DIVULG 29-03-2012 PUBLIC 30-03-2012 REVJMG v. 63, n. 200, 2012, p. 351-355. Disponível em: http://redir.stf.jus.br/paginadorpub/ paginador.jsp?docTP=TP\&docID=1871030 . Acesso em: 25 nov. 2019.

14 BRASIL. [Constituição (1988)]. Constituição da República Federativa do Brasil de 1988. Artigo 98 do Ato das Disposiçóes Constitucionais Transitórias: O número de defensores públicos na unidade jurisdicional será proporcional à efetiva demanda pelo serviço da Defensoria Pública e à respectiva populaçáo. $₫ 1^{\circ}$. No prazo de 8 (oito) anos, a União, os Estados e o Distrito Federal deverão contar com defensores públicos em todas as unidades jurisdicionais, observado o disposto no caput deste artigo.

15 BRASIL. Lei Complementar n. 132, de 7 de outubro de 2009. Altera dispositivos da Lei Complementar ne80, de 12 de janeiro de 1994, que organiza a Defensoria Pública da União, do Distrito Federal e dos Territórios e prescreve normas gerais para sua organização nos Estados, e da Lei n ${ }^{\circ}-1.060$, de 5 de fevereiro de 1950, e dá outras providências.

16 ASSIS, Victor Hugo Siqueira de. Defensoria Pública: Histórico, Afirmaçâo e Novas Perspectivas. Revista da Defensoria Pública da Uniáo, Brasília., p. 185-209, jan/dez 2019. 
fensoria Pública no país. A instituição deixava finalmente para trás um perfil meramente individualista para adotar o solidarismo jurídico.

Afirmando seu caráter vanguardista, a Lei Complementar $\mathrm{n}^{\circ}$ 132/2009 já inicia, em seu artigo $1^{\circ}$, com a substancial alteraçáo da definição legal de Defensoria Pública. O texto, que seria posteriormente replicado pela Emenda Constitucional no 80/2014 (alterando o artigo 134 da Constituição Federal), conceitua a instituição como permanente, sendo expressão e instrumento do regime democrático, além de responsável pela promoção dos direitos humanos, seja no âmbito individual ou coletivo.

$[\ldots]$

Aprofundando essa lógica, a Lei Complementar no 132/2009 deu nova feição ao artigo $4^{\circ}$ da Lei Complementar no 80/1994, aperfeiçoando as atribuiçóes institucionais com um aspecto menos individualista e demandista, ao trazer novas funçôes com caráter mais inclusivo, resolutivo, educativo e solidário. Destacam-se, nesse contexto, a busca prioritária pela soluçáo extrajudicial dos conflitos, a educação em direitos, o acesso aos sistemas internacionais de proteção dos direitos humanos, a consolidação da legitimidade para as açôes coletivas, a participação em conselhos de direitos e a possibilidade de convocação de audiências públicas.

Como se vê, os novos contornos conferidos pelas legislações retromencionadas, por si sós, revelam o reconhecimento da sociedade brasileira acerca da relevante missáo desempenhada pela Defensoria Pública em nosso ordenamento jurídico, em prol da promoção do bem-estar de todos e de uma sociedade livre, justa e solidária, através da defesa, judicial e extrajudicial, dos direitos individuais e coletivos dos necessitados.

Ademais, a novel configuração normativa contribuiu decisivamente para a consolidação da Defensoria Pública no cenário político-jurídico-social brasileiro, ao destacá-la dos demais Poderes constitucionais, dotando-a de autonomia funcional, administrativa e financeira, essa última expressa na capacidade de elaborar sua proposta orçamentária, dentro dos limites legais, e de gerir e aplicar os respectivos recursos.

Oportunamente, Diogo Esteves e Franklyn Silva ${ }^{17}$ asseveram:

[...] A autonomia da Defensoria Pública deve ser compreendida como uma decorrência lógica de sua própria função constitucional. Como "Função Essencial à Justiça", a Defensoria Pública encontrase encarregada da irrenunciável missão constitucional de exercer o controle das funçóes estatais, neutralizando o abuso e a arbitrariedade emergentes da luta de classes. Desse modo, para que possa atuar de maneira ativa na defesa da ordem jurídica democrática do país, torna-se imprescindível que a Defensoria Pública possua a necessária autonomia em relação aos demais Poderes do Estado. Não só

17 ESTEVES, Diogo; SILVA, Franklyn Roger Alves. Princípios Institucionais da Defensoria Pública. 3. ed. Rio de Janeiro: Forense, 2018. 
autonomia funcional, mas autonomia administrativa e financeira, evitando-se pressões indiretas e retaliações orçamentárias indevidas por parte das demais estruturas estatais, em resposta à eventual e incômoda atuação dos Defensores Públicos.

Sendo assim, adotando como elemento balizador o perfil constitucional da Defensoria Pública ora delineado - que a reconhece como instituição permanente e essencial à função jurisdicional do Estado, dotada de autonomia funcional, administrativa, e da iniciativa de proposta orçamentária, dentro dos limites da lei - , é que passaremos a refletir sobre o tema do presente trabalho consubstanciado na questáo constitucional agitada no Recurso Extraordinário n. 1.140.005 RG (Tema 1002), assim delimitada: "saber se a proibição ao recebimento de honorários advocatícios pela Defensoria Pública, quando representa litigante vencedor em demanda ajuizada contra o ente ao qual é vinculada, viola a sua autonomia funcional, administrativa e institucional”.

\section{DOS HONORÁRIOS ADVOCATÍCIOS DEVIDOS À DEFENSORIA PÚBLI- CA - ASPECTOS NORMATIVO E JURISPRUDENCIAL}

Antes de adentrarmos na controvérsia relativa ao cabimento dos honorários advocatícios à Defensoria Pública quando em litígio contra o ente federativo que a integra, de que trata o Recurso Extraordinário n. 1.140.005 RG (Tema 1002), afigura-se pertinente verificar o tratamento atual conferido à matéria pelos diplomas normativos e pela jurisprudência dos Tribunais Superiores.

Vejamos. O princípio da sucumbência, agasalhado pelo Direito Processual Civil brasileiro, estabelece que a parte vencida se torna obrigada a pagar $(i)$ as despesas processuais antecipadas pelo vencedor (artigo $82, \$ 2^{\circ}$, do $\left.\mathrm{CPC}\right)^{18}$ e $($ ii) os honorários advocatícios devidos à parte contrária (artigo 85 do $\mathrm{CPC})^{19}$.

Em se tratando de beneficiário da justiça gratuita, sendo este vencido na lide, será condenado ao pagamento das custas processuais e honorários advocatícios, sendo certo que a exigibilidade da obrigação se torna suspensa no prazo legal de cinco anos, nos termos do artigo $98, \$ \$ 2^{\circ}$ e $3^{0^{20}}$ do Código de Processo Civil.

De outro giro, sagrando-se vencedor o beneficiário da justiça gratuita, a parte contrária

18 BRASIL. Lei ${ }^{\circ}$ 13.105, de 16 de março de 2015. Código de Processo Civil. Art. 82 [...] $\$ 2$. A sentença condenará o vencido a pagar ao vencedor as despesas que antecipou.

19 BRASIL. Lei $\mathbf{n}^{\mathbf{0}} \mathbf{1 3 . 1 0 5}$, de 16 de março de 2015. Código de Processo Civil. Art. 85. A sentença condenará o vencido a pagar honorários ao advogado do vencedor.

20 BRASIL. Lei n. ${ }^{\circ}$ 13.105, de 16 de março de 2015. Código de Processo Civil. Art. 98 [...] \$2º A concessão de gratuidade não afasta a responsabilidade do beneficiário pelas despesas processuais e pelos honorários advocatícios decorrentes de sua sucumbência. $\$ 3^{\circ}$ Vencido o beneficiário, as obrigaçóes decorrentes de sua sucumbência ficarão sob condição suspensiva de exigibilidade e somente poderão ser executadas se, nos 5 (cinco) anos subsequentes ao trânsito em julgado da decisão que as certificou, o credor demonstrar que deixou de existir a situação de insuficiência de recursos que justificou a concessão de gratuidade, extinguindo-se, passado esse prazo, tais obrigaçôes do beneficiário. . 
será também condenada ao pagamento das despesas processuais e honorários advocatícios ao prestador da assistência gratuita, conforme entendimento sedimentado na Súmula 450/STF"21: "São devidos honorários de advogado sempre que vencedor o beneficiário de justiça gratuita”.

Estando a parte assistida pela Defensoria Pública, estabelece o artigo $4^{\circ}$, inciso XXI, da Lei Complementar n. 80/1994², com a redaçáo dada pela Lei Complementar n. $132 / 2009$, que caberá à própria Instituição executar e receber as verbas sucumbenciais decorrentes de sua atuação, inclusive quando devida por quaisquer entes públicos, as quais serão recolhidas em favor de fundos próprios. Por oportuno, confira-se o exato teor do dispositivo citado, verbis:

$$
\text { Art. } 4^{-}[\ldots]
$$

XXI - executar e receber as verbas sucumbenciais decorrentes de sua atuação, inclusive quando devidas por quaisquer entes públicos, destinando-as a fundos geridos pela Defensoria Pública e destinados, exclusivamente, ao aparelhamento da Defensoria Pública e à capacitação profissional de seus membros e servidores (grifo nosso).

Desse modo, não pairando dúvidas acerca da legitimidade da Defensoria Pública para litigar contra as pessoas jurídicas de direito público, nos termos prescritos pelo parágrafo $2^{\circ}$ do artigo $4^{\circ}$ da Lei Complementar 80/1994²3, o recebimento dos honorários advocatícios respectivos seria mero consectário legal, especialmente a partir da Lei Complementar $\mathrm{n}$. $132 / 2009$.

Todavia, a jurisprudência do Superior Tribunal de Justiça albergou entendimento diverso.

A pesquisa jurisprudencial no sítio eletrônico do Superior Tribunal de Justiça revela que, desde julgados mais remotos, a exemplo do Recurso Especial n. 541.440/RS, Rel. Min. José Delgado, DJ 20/10/2003, o entendimento da Corte se voltou contra o pagamento da verba honorária advocatícia nas demandas patrocinadas pela Defensoria Pública em que a parte vencida fosse o ente público ao qual ela estivesse vinculada.

Isso porque, de acordo os fundamentos que embasam essa construção pretoriana, havendo litígio entre pessoas vinculadas à mesma fazenda pública e sendo a Defensoria Pública "mero órgão estadual", sem personalidade jurídica e capacidade processual, ao fim e ao cabo, o pagamento da verba honorária se destinaria, na verdade, ao próprio ente federado, eis que caracterizada estaria a confusão patrimonial entre credor e devedor. Nesse sentido,

\footnotetext{
21 BRASIL. Supremo Tribunal Federal. Súmula 450. São devidos honorários de advogado sempre que vencedor o beneficiário de justiça gratuita. Sessão Plenária de 01/10/1964.

22 BRASIL. Lei Complementar 80, de 12 de janeiro de 1994 (Organiza a Defensoria Pública da União, do Distrito Federal e dos Territórios e prescreve normas gerais para sua organização nos Estados, e dá outras providências).

23 BRASIL. Lei Complementar 80, de 12 de janeiro de 1994 (Organiza a Defensoria Pública da União, do Distrito Federal e dos Territórios e prescreve normas gerais para sua organização nos Estados, e dá outras providências). Art. $4^{\circ}$ São funçóes institucionais da Defensoria Pública, dentre outras: [...] $\$ 2^{\circ}$ As funçóes institucionais da Defensoria Pública serão exercidas inclusive contra as Pessoas Jurídicas de Direito Público.
} 
explicita a ementa do mencionado Recurso Especial n. 541.440/RS, verbis:

PROCESSUAL CIVIL. DEFENSORIA PÚBLICA REPRESENTANDO LITIGANTE VENCEDOR EM DEMANDA CONTRA O ESTADO. PAGAMENTO DE HONORÁRIOS ADVOCATÍCIOS. IMPOSSIBILIDADE. CONFUSÃO ENTRE CREDOR E DEVEDOR. DEFENSORIA. ÓRGÃO ESTATAL. PRECEDENTES.

1. A Defensoria Pública é órgão do Estado, por isso que não pode recolher honorários sucumbenciais decorrentes de condenação contra a fazenda em causa patrocinada por Defensor Público. Confusão. Aplicação do art. 1.049 do Código Civil. (REsp no 469662/RS, 1a Turma, DJ de 23/06/2003, Rel. Min. LUIZ FUX)

2. Os honorários de advogado nas açôes patrocinadas pela Defensoria Pública destinam-se ao próprio Estado. $\mathrm{O}$ fato de haver um fundo orçamentário com finalidade específica (criado pela Lei Estadual do RS no 10.298/94) é matéria contábil-financeira que não altera a situação jurídica de ser o credor dessa verba a Fazenda Estadual e não a parte ou a própria Defensoria, já que esta não detém personalidade jurídica, sendo órgão do Estado.

3. O destino do produto das receitas do Estado, decorrentes de sucumbência nos processos em que seja parte, é irrelevante na relação jurídica que trave com terceiros.

4. A Defensoria Pública é mero, não menos importantíssimo, órgão estadual, no entanto, sem personalidade jurídica e sem capacidade processual, denotando-se a impossibilidade jurídica de acolhimento do pedido da concessão da verba honorária advocatícia, por se visualizar a confusão entre credor e devedor.

5. Recurso provido. ${ }^{24}$

Posteriormente, em 3/6/2009, foi submetido à apreciação da Corte Especial do Superior Tribunal de Justiça o Recurso Especial n. 1.108.013/RJ, sob o rito dos Recursos Repetitivos (artigo 543-C do Código de Processo Civil de 1973), para dirimir a seguinte controvérsia:

"existência ou não de confusão entre credor e devedor, no que se refere ao recebimento de honorários advocatícios sucumbenciais em demanda patrocinada por Defensor Público Estadual contra Município, à luz do art. 381 do Código Civil (art. 1.049 do diploma anterior), dispositivo legal que se encontra assim redigido: Art. 381. Extingue-se a obrigação, desde que na mesma pessoa se confundam as qualidades de credor e devedor."

Do referido julgamento, duas teses restaram firmadas. A primeira (Tema 129) reconheceu à Defensoria Pública o direito ao recebimento dos honorários advocatícios quando a

$24 \quad$ BRASIL. Superior Tribunal de Justiça. Recurso Especial (REsp) 541.440/RS, Rel. Ministro JOSÉ DELGADO, PRIMEIRA TURMA, julgado em 04/09/2003, DJ 20/10/2003, p. 235. 
atuação se dá em face de ente federativo diverso do qual é parte integrante.

Portanto, quando a Defensoria Pública Estadual atua contra Município ou a Defensoria Pública da União litiga contra Estado membro, por exemplo, é cabível a condenação ao pagamento de honorários advocatícios, porque, nessas hipóteses, inexistindo qualquer vinculação entre as partes, não há que se falar em confusão entre credor e devedor.

A segunda tese (Tema 128), a contrario sensu, firmou-se no sentido de que não são devidos honorários advocatícios quando a Defensoria Pública atua contra a pessoa jurídica de direito público à qual pertença, em razão da confusão que surge entre credor e devedor, consoante explicitam os fundamentos exarados no voto condutor da lavra da Ministra Relatora Eliana Calmon ${ }^{25}$, verbis:

[...] O texto constitucional é intuitivo quanto à existência de Defensoria Pública da Uniáo e do Distrito Federal e dos Territórios, além da dos Estados, constituindo, sob a ótica do Direito Administrativo, órgãos desses entes da Federação.

Assim, na relação jurídica processual contra o poder público ou por ele iniciada, em que um dos pólos se encontra um juridicamente necessitado, surge o cenário propício ao aparecimento da confusão, no que toca aos honorários advocatícios, a depender da sucumbência.

Sagrando-se vitorioso o necessitado assistido pela Defensoria Pública, há que se averiguar se o derrotado porventura não é o ente público da qual ela é parte, pois configurada essa situação, é indiscutível que o credor dos honorários advocatícios será em última análise também o devedor.

Nessa esteira, a orientação pretoriana foi se firmando a ponto de, em 3/3/2010, portanto após a redação dada pela Lei Complementar n. 132/2009 à Lei Complementar 80/94, a Corte Superior de Justiça editar o verbete sumular $421^{26}$, cujo teor reza: "Os honorários advocatícios não são devidos à Defensoria Pública quando ela atua contra a pessoa jurídica de direito público à qual pertença.”

Acrescente-se que, em 16/02/2011, ao julgar o Recurso Especial n. 1.199.715/RJ ${ }^{27}$, sob o rito dos recursos repetitivos, a Corte Especial do Superior Tribunal de Justiça ampliou o alcance da Súmula 421/STJ para nela incluir a Administração Indireta detentora de personalidade jurídica de direito público.

\footnotetext{
25 BRASIL. Superior Tribunal de Justiça. Recurso Especial (REsp) 1108013/RJ, Rel. Ministra ELIANA CALMON, CORTE ESPECIAL, julgado em 03/06/2009, DJe 22/06/2009.

26 BRASIL. Superior Tribunal de Justiça. Súmula 421. Os honorários advocatícios não são devidos à Defensoria Pública quando ela atua contra a pessoa jurídica de direito público à qual pertença. Corte Especial, julgado em 03/0382010, DJe 11/03/2010. .

27 Na hipótese versada no Recurso Especial n. 1.199.715/RJ, reconheceu-se haver confusão entre a Defensoria Pública fluminense e a RIOPREVIDÊNCIA (Fundo Único de Previdência Social do Estado do Rio de janeiro), Autarquia Previdenciária Estadual, em razão de os recursos públicos envolvidos serem oriundos do Estado do Rio de Janeiro.
} 
Evidencia-se, pois, que a jurisprudência consolidada no Superior Tribunal de Justiça adota o instituto da confusão como fundamento precípuo para determinar o cabimento ou não dos honorários advocatícios.

A confusão, vale relembrar, ocorre quando uma única pessoa reúne as qualidades de credor e devedor, ocasionando a extinção da obrigação e encontra previsão no artigo 381 do Código Civil ${ }^{28}$, verbis: "Extingue-se a obrigação, desde que na mesma pessoa se confundam as qualidades de credor e devedor".

Carlos Roberto Gonçalves ${ }^{29}$ apresenta o seguinte conceito de confusão, verbis:

[...] A obrigação pressupóe a existência de dois sujeitos: o ativo e o passivo. Credor e devedor devem ser pessoas diferentes. Se essas duas qualidades, por alguma circunstância, encontrarem-se em uma só pessoa, extingue-se a obrigação, porque ninguém pode ser juridicamente obrigado para consigo mesmo ou propor demanda contra si próprio.

Em síntese, de acordo com a jurisprudência dominante do Superior Tribunal de Justiça, há confusão na hipótese de a Fazenda Pública ser condenada ao recolhimento dos honorários em favor da Defensoria Pública que lhe integra, pois, sendo o orçamento da Defensoria Pública oriundo desse mesmo cofre público, o valor a ser pago reverteria para a própria Fazenda.

Vale dizer, o fato de o orçamento da Defensoria Pública estar diretamente atrelado ao do ente federativo cuja estrutura integra é o que ensejaria a confusão e obstaria o pagamento dos honorários advocatícios.

Tal é o entendimento que prevalece atualmente na jurisprudência do Superior Tribunal de Justiça, tal como explicitado no Recurso Especial n. 1786939/AM ${ }^{30}$.

De outro giro, no âmbito do Supremo Tribunal Federal, a controvérsia concernente à possibilidade de recebimento de honorários advocatícios pela Defensoria Pública em demandas ajuizadas contra o próprio Estado ao qual o referido órgão está vinculado foi submetida à apreciação do Tribunal Pleno, pela primeira vez, em 6/11/2008, nos autos do Recurso Extraordinário n. 592.730-0/RS ${ }^{31}$.

Naquela ocasião, concluiu-se pela ausência de repercussão geral da matéria, ao fundamento de que a questão estaria circunscrita à "definição acerca da titularidade, no âmbito

\footnotetext{
28 BRASIL. Lei $\mathbf{n}^{\circ} \mathbf{1 0 . 4 0 6}$, de 10 de janeiro de 2002. Institui o Código Civil.

29 GONÇALVES, Carlos Roberto. Direito Civil Brasileiro 2: Teoria Geral das Obrigações, 2019.

30 BRASIL. Superior Tribunal de Justiça. Recurso Especial (REsp) 1786939/AM, Rel. Ministro HERMAN BENJAMIN, SEGUNDA TURMA, julgado em 21/03/2019, DJe 30/05/2019.

31 BRASIL. Supremo Tribunal Federal. Repercussão Geral em Recurso Extraordinário (RE) 592730 RG, Relator(a): Min. MENEZES DIREITO, julgado em 06/11/2008, DJe-222 DIVULG 20-11-2008 PUBLIC 21-11-2008 EMENT VOL-02342-21 PP-04192. r/paginadorpub/paginador..
} 
estadual, dos recursos públicos disputados"32.

O entendimento exarado no Recurso Extraordinário n. 592.730-0/RS aliado à aprovação da Súmula 421 pelo Superior Tribunal de Justiça, que tem o condão de obstar a subida de novos Recursos Extraordinários, tornaram-se fortes empecilhos à reapreciação do tema pela Corte Suprema, tal como asseverado pelo Ministro Roberto Barroso, no respectivo voto proferido nos autos do RE 1.140.005 $\mathrm{RG}^{33}$.

Surpreendentemente, dissentindo da própria orientação pretoriana, o Plenário do Supremo Tribunal Federal, em 9/8/2017, ao julgar o Agravo Regimental na Ação Rescisória n. $1.937^{34}$, admitiu a possibilidade de a União ser condenada a pagar verbas sucumbenciais à Defensoria Pública, com base nos fundamentos exarados no voto condutor da lavra do Ministro Relator Gilmar Mendes ${ }^{35}$, verbis:

[...] após as Emendas Constitucionais 45/2004, 74/2013 e 80/2014, houve mudança da legislação correlata à Defensoria Pública da União, permitindo a condenação da União em honorários advocatícios em demandas patrocinadas por aquela instituição de âmbito federal, diante de sua autonomia funcional, administrativa e orçamentária, cuja constitucionalidade foi reconhecida na ADI 5296 MC, Rel. Min. Rosa Weber, Tribunal Pleno, Dje 11.11.2016.

Esse julgamento promoveu verdadeira reviravolta no cenário jurídico, a ponto de a própria Corte Suprema admitir a possibilidade de reconsiderar o posicionamento até entáo adotado e concluir pela necessidade de revisitar o entendimento esposado no RE 592.730, mediante o reconhecimento da repercussão geral da matéria, nos autos do RE 1.140.005 RG, cujo acórdão, julgado em 3/8/2018, encontra-se assim ementado, verbis:

Direito Constitucional. Recurso Extraordinário. Pagamento de honorários à Defensoria Pública que litiga contra o ente público ao qual se vincula. Presença de repercussão geral.

1. A decisão recorrida excluiu a condenação da União ao pagamento de honorários advocatícios à Defensoria Pública da União.

2. A possibilidade de se condenar ente federativo a pagar honorários advocatícios à Defensoria Pública que o integra teve a repercussão geral negada no RE 592.730, Rel. Min. Menezes Direito, paradigma do tema no 134 .

\footnotetext{
$32 \quad$ Ibid.

33 BRASIL. Supremo Tribunal Federal. Repercussão Geral em Recurso Extraordinário (RE) 1140005 RG, Relator(a): Min. ROBERTO BARROSO, julgado em 03/08/2018, PROCESSO ELETRÔNICO DJe162 DIVULG 09-08-2018 PUBLIC 10-08-2018.

34 BRASIL. Supremo Tribunal Federal. Agravo Regimental na açáo Rescisória. AR 1937 AgR, Relator(a): Min. GILMAR MENDES, Tribunal Pleno, julgado em 30/06/2017, ACÓRDÃO ELETRÔNICO DJe-175 DIVULG 08-08-2017 PUBLIC 09-08-2017.

35 Idem
} 
3. As Emendas Constitucionais no 74/2013 e no 80/2014, que asseguraram autonomia administrativa às Defensorias Públicas, representaram alteração relevante do quadro normativo, o que justifica a rediscussão da questấo.

4. Constitui questão constitucional relevante definir se os entes federativos devem pagar honorários advocatícios às Defensorias Públicas que os integram.

5. Repercussão geral reconhecida. ${ }^{36}$

De acordo com o voto condutor da lavra do Ministro Roberto Barroso, proferido no referido RE 1.140.005 RG, a mudança de entendimento jurisprudencial no âmbito do Supremo Tribunal Federal, representada pelo julgamento da Ação Rescisória n. 1.937, somada ao advento das Emendas Constitucionais 45/2004, 74/2013 e 80/2014 - que, alterando o artigo 134 da Constituiçáo Federal, reforçou o papel institucional da Defensoria Pública, bem como assegurou sua autonomia funcional, administrativa e orçamentária -, aliada, ainda, ao fato de a maioria das Defensorias Públicas enfrentar problemas de estruturação de seus órgãos, que poderiam ser atenuados com o recebimento de honorários, constituíram fundamentos suficientes para que, nessa nova conjuntura, fosse reconhecida a repercussão geral da matéria.

Eis, portanto, em linhas singelas, o contexto atual a nortear as reflexóes acerca da possibilidade de pagamento de honorários advocatícios à Defensoria Pública quando em litígio contra o ente público a que pertence.

Diante do cenário retrodelineado, consideramos ser grande a possibilidade de a controvérsia em apreço ganhar novo desfecho, de modo a prevalecer o entendimento favorável ao pagamento de honorários advocatícios à Defensoria Pública, quando litiga contra qualquer ente público, indiscriminadamente, em razão dos argumentos a seguir delineados.

\section{DA ADMISSIBILIDADE DO PAGAMENTO DE HONORÁRIOS ADVOCA- TÍCIOS À DEFENSORIA PÚBLICA QUANDO LITIGA CONTRA O ENTE AO QUAL É VINCULADA}

A possibilidade de a Defensoria Pública receber honorários advocatícios quando litiga contra o ente ao qual é vinculada encontra o devido amparo normativo-jurisprudencial.

Conforme mencionamos, por força das Emendas Constitucionais nos. 45/04, 75/13 e 80/14 e da Lei Complementar 132/2009, a Defensoria Pública desfruta, hoje, de elevado grau de autonomia e de relevantes prerrogativas institucionais, a ponto de não mais ser possível atribuir-lhe a condição de "mero órgão estadual", tal como asseverado pela juris-

36 BRASIL. Supremo Tribunal Federal. Recurso Extraordinário (RE) 1140005 RG, Relator(a): Min. ROBERTO BARROSO, julgado em 03/08/2018, PROCESSO ELETRÔNICO DJe-162 DIVULG 09-082018 PUBLIC 10-08-2018. 
prudência que supedaneou a edição da Súmula 421/STJ ${ }^{37}$.

Aliás, a concepção atual da Defensoria Pública, como órgão autônomo e essencial para o funcionamento da Justiça, não deflui estritamente do aspecto normativo, pois táo importante quanto a ampliação legislativa retromencionada vem sendo o papel desempenhado pelo Supremo Tribunal Federal e pelo Superior Tribunal de Justiça em prol do fortalecimento e consolidação dessa Instituição.

Nessa linha, calha mencionar, ilustrativamente, ter o Supremo Tribunal Federal declarado a inconstitucionalidade de lei estadual que atribui ao chefe do Poder Executivo estadual competências administrativas no âmbito da Defensoria Pública (ADI 5286) ${ }^{38}$; de normas estaduais que vinculem a Defensoria Pública à Secretaria de Estado (ADI 3965) ${ }^{39}$; de Lei de Diretrizes Orçamentárias que seja concebida sem a participação da Defensoria Pública para elaborar as respectivas propostas orçamentárias (ADI 5381) ${ }^{40}$; de redução unilateral pelo Poder Executivo de proposta orçamentária da Defensoria Pública elaborada de acordo com a LDO (ADI 5287) $)^{41}$, e, ainda, reafirmado o dever do Poder Executivo de efetuar os repasses de duodécimo na forma do art. $168 \mathrm{da}$ CF/88(ADPF 339) ${ }^{42}$, dentre outros julgados correlatos.

De outro giro, no tocante à ampliação da atuação institucional, apenas para exemplificar, o Supremo Tribunal Federal declarou a constitucionalidade do art. $5^{\circ}$, II, da Lei ${ }^{\circ}$ $7.347 / 85$, com redaçáo dada pela Lei $\mathrm{n}^{\circ} 11.448 / 07$, reconhecendo legitimidade à Defensoria Pública para propor ação civil pública em defesa de direitos difusos, coletivos, e individuais homogêneos(ADI 3943) ${ }^{43}$.

O Superior Tribunal de Justiça, por seu turno, ao interpretar os requisitos legais para a atuação coletiva da Defensoria Pública, "encampa exegese ampliativa da condição jurídica de 'necessitado', de modo a possibilitar sua atuação em relaçẫo aos necessitados jurídicos

37 BRASIL. Superior Tribunal de Justiça. Recurso Especial (REsp) 604.977/RS, Rel. Ministro JOSÉ DELGADO, PRIMEIRA TURMA, julgado em 17/02/2004, DJ 03/05/2004, p. 123.

38 BRASIL. Supremo Tribunal Federal. Açáo Direta de Inconstitucionalidade (ADI) 5286, Relator(a): Min. LUIZ FUX, Tribunal Pleno, julgado em 18/05/2016, PROCESSO ELETRÔNICO DJe-159 DIVULG 29-07-2016 PUBLIC 01-08-2016.

39 BRASIL. Supremo Tribunal Federal. Açáo Direta de Inconstitucionalidade (ADI) 3965, Relator(a): Min. CÁRMEN LÚCIA, Tribunal Pleno, julgado em 07/03/2012, ACÓRDÃO ELETRÔNICO DJe-065 DIVULG 29-03-2012 PUBLIC 30-03-2012 REVJMG v. 63, n. 200, 2012, p. 351-355).

40 BRASIL. Supremo Tribunal Federal. Açáo Direta de Inconstitucionalidade (ADI) 5381 MCRef, Relator(a): Min. ROBERTO BARROSO, Tribunal Pleno, julgado em 18/05/2016, PROCESSO ELETRÔNICO DJe-256 DIVULG 30-11-2016 PUBLIC 01-12-2016.

${ }^{41}$ BRASIL. Supremo Tribunal Federal. Açáo Direta de Inconstitucionalidade (ADI) 5287, Relator(a): Min. LUIZ FUX, Tribunal Pleno, julgado em 18/05/2016, PROCESSO ELETRÔNICO DJe-194 DIVULG 09-09-2016 PUBLIC 12-09-2016.

42 BRASIL. Supremo Tribunal Federal. Arguiçáo de Descumprimento de Preceito Fundamental (ADPF) 339, Relator(a): Min. LUIZ FUX, Tribunal Pleno, julgado em 18/05/2016, PROCESSO ELETRÔNICO DJe-159 DIVULG 29-07-2016 PUBLIC 01-08-2016.

43 BRASIL. Supremo Tribunal Federal. Açáo Direta de Inconstitucionalidade (ADI) 3943, Relator(a): Min. CÁRMEN LÚCIA, Tribunal Pleno, julgado em 07/05/2015, ACÓRDÃO ELETRÔNICO DJe-154 DIVULG 05-08-2015 PUBLIC 06-08-2015. 
em geral, não apenas dos hipossuficientes sob o aspecto econômico" ${ }^{4445}$. E mais, ressalta que a interpretação dos arts. 134 e $5^{\circ}$, LXXXIV, da CF, deve ser ampla e abstrata, 'bastando que possa haver a existência de um grupo de hipossuficientes, independentemente de alcançar de forma indireta e eventual outros grupos mais favorecidos economicamente" ${ }^{46}$.

Sendo assim, sem maiores delongas e para se evitar o desvio do tema em análise, é fato ter as últimas décadas testemunhado, nos aspectos normativo e jurisprudencial, a ampliação do mister exercido pela Defensoria Pública, reconhecendo, outrossim, sua relevância para a proteção do regime democrático e para a promoção dos direitos humanos e dos direitos individuais e coletivos.

Nesse contexto em que o Supremo Tribunal Federal declara a inconstitucionalidade de "medidas que resultem em subordinação da Defensoria Pública ao Poder Executivo, por implicarem violação da autonomia funcional e administrativa da instituição" (ADPF 307 $\mathrm{MC})^{47}$, ao mesmo tempo em que reconhece que "a autonomia administrativa e financeira da Defensoria Pública qualifica-se como preceito fundamental” (ADPF $307 \mathrm{MC}$ ) 48 , é que se evidencia a insustentabilidade do entendimento expresso no verbete sumular 421/STJ ante o atual regramento constitucional pertinente à Defensoria Pública.

Aliás, cumpre abrir um parêntese para destacar que a Súmula 421/STJ, apesar de ter sido editada em 3/3/2010 e publicada em 11/3/2010, reflete entendimento jurisprudencial firmado antes do advento da Lei Complementar 132/2009 ${ }^{49}$, que entrou em vigor em 7 de outubro de 2009 . Ou seja, o fundamento sumular é baseado em precedentes anteriores $^{50}$ à novel legislação.

\footnotetext{
44 BRASIL. Superior Tribunal de Justiça. Agravo Interno nos Embargos de Declaraçáo no Recurso Especial (AgInt nos EDcl no REsp) 1529933/CE, Rel. Ministro BENEDITO GONÇALVES, PRIMEIRA TURMA, julgado em 20/05/2019, DJe 22/05/2019.

45 BRASIL. Superior Tribunal de Justiça. Embargos de Divergência em Recurso Especial (EREsp) 1192577/RS, Rel. Ministra LAURITA VAZ, CORTE ESPECIAL, julgado em 21/10/2015, DJe 13/11/2015.

46 BRASIL. Superior Tribunal de Justiça. Agravo Interno no Recurso Especial (AgInt no REsp ) 1418091/ SP, Rel. Ministro MARCO AURÉLIO BELLIZZE, TERCEIRA TURMA, julgado em 09/09/2019, DJe 12/09/2019.

47 BRASIL. Supremo Tribunal Federal. Arguiçáo de Descumprimento de Preceito Fundamental (ADPF) 307MC, Relator(a): Min. DIAS TOFFOLI, Tribunal Pleno, julgado em 19/12/2013, PROCESSO ELETRÔNICO Dje-060 DIVULG 26-03-2014 PUBLIC 27-03-2014.

48 Idem.

49 A partir da Lei Complementar 132/09, os honorários de sucumbência são devidos à Defensoria Pública, e não à pessoa jurídica de direito público a qual ela pertence (União, Distrito Federal e Estados), como antes acontecia, consoante art. 4º, XXI: Art. $4^{\circ}$ - São funçóes institucionais da Defensoria Pública, dentre outras: [...] XXI - executar e receber as verbas sucumbenciais decorrentes de sua atuação, inclusive quando devidas por quaisquer entes públicos, destinando-as a fundos geridos pela Defensoria Pública e destinados, exclusivamente, ao aparelhamento da Defensoria Pública e à capacitação profissional de seus membros e servidores.

50 De acordo com a pesquisa realizada no sítio eletrônico do Superior Tribunal de Justiça <scon.sti.jus.br/ SCON/pesquisar.jsp>, o Enunciado da Súmula 421 apoiou-se, dentre outros, nos seguintes precedentes: REsp 1108013/RJ, decisão: 03/06/2009, DJe 22/06/2009; AgRg no REsp 1084534/MG, Decisão: 18/12/2008, DJe 12/02/2009; AgRg no Resp 1054873/RS, Decisão 11/11/2008, DJe 15/12/2008; REsp 740568/RS, Decisão 16/10/2008, DJe 10/11/2008.
} 
Destarte, por razóes óbvias, os acórdãos que supedanearam a edição da Súmula 421/STJ, todos anteriores a 2008, não consideraram o alcance que a jurisprudência superveniente dos Tribunais Superiores conferiram à Instituição, bem como as alteraçóes legislativas posteriores, especialmente a Lei Complementar 132/2009, que estabeleceu o pagamento dos honorários de sucumbência à Defensoria Pública, e não à pessoa jurídica de direito público a qual ela pertence.

Por conseguinte, é nítido o descompasso entre a jurisprudência derivada da Súmula 421/ STJ, que ainda hoje prevalece no Superior Tribunal de Justiça, e o cenário normativo-jurisprudencial retrodelineado, de modo a recomendar a superação deste preceito sumular.

Mas não é só. O fundamento basilar da Súmula 421/STJ para obstar o pagamento da verba honorária na hipótese em análise, qual seja, a confusáo patrimonial, prevista no art. 381 do Código Civil, não se coaduna com o status constitucional ora desfrutado pela Defensoria Pública e, principalmente, não configura a solução adequada para resolver específica questão relativa a orçamento público.

Vejamos. Em razão das Emendas Constitucionais n.s 45/2004 e 74/2013, que conferiram às Defensorias Públicas a iniciativa própria para a elaboração das respectivas propostas orçamentárias, observados os limites legais, e da redação atual da Lei Complementar 80/1994 ${ }^{51}$, a Defensoria Pública possui, atualmente, a mesma autonomia orçamentária desfrutada pelo Ministério Público (artigo 127, $\$ \$ 2^{\circ}$ a $6^{\circ}$, da $C R F B^{52}$ ) e pelo Poder Judiciário (artigo 99, $\$ 1^{\circ}$, da $\mathrm{CRFB}^{53}$ ), conforme explicitado pelo Ministro Roberto Barroso $^{54}$, no respectivo voto condutor proferido nos autos da ADI $5381 \mathrm{MC}$, verbis:

[...] 16. O art. $134, \$ 2^{\circ}$, da Constituição Federal também estabelece que a proposta de orçamento da Defensoria Pública deve ser elaborada dentro dos limites estipulados na Lei de Diretrizes Orçamentárias. Se, então, a participação dos tribunais na fixação dos limites aos seus orçamentos decorre da sua própria autonomia financeira,

51 BRASIL. Lei Complementar n. 80, de 12 de janeiro de 1994. Organiza a Defensoria Pública da União, do Distrito Federal e dos Territórios e prescreve normas gerais para sua organização nos Estados, e dá outras providências.

52 BRASIL. [Constituição (1988)]. Constituição da República Federativa do Brasil de 1988. Art. 127 [...] \$ 20 Ao Ministério Público é assegurada autonomia funcional e administrativa, podendo, observado o disposto no art. 169, propor ao Poder Legislativo a criaçáo e extinçáo de seus cargos e serviços auxiliares, provendo-os por concurso público de provas ou de provas e títulos, a política remuneratória e os planos de carreira; a lei disporá sobre sua organizaçáo e funcionamento. (Redaçáo dada pela Emenda Constitucional n. 19, de 1998); $\$ 3^{\circ}$ O Ministério Público elaborará sua proposta orçamentária dentro dos limites estabelecidos na lei de diretrizes orçamentárias [...] (incluído pela Emenda Constitucional n. 45, de 2004).

53 BRASIL. [Constituição (1988)]. Constituição da República Federativa do Brasil de 1988. Art. 99. Ao Poder Judiciário é assegurada autonomia administrativa e financeira. $\$ 1^{\circ}$ Os tribunais elaborarão suas propostas orçamentárias dentro dos limites estipulados conjuntamente com os demais Poderes na lei de diretrizes orçamentárias.

54 BRASIL. Supremo Tribunal Federal. Açáo Direta de Inconstitucionalidade (ADI) 5381 MC Ref, Relator(a): Min. ROBERTO BARROSO, Tribunal Pleno, julgado em 18/05/2016, PROCESSO ELETRÔNICO DJe-256 DIVULG 30-11-2016 PUBLIC 01-12-2016. 
não há razão para não reconhecer também à Defensoria Pública o direito de estipular, conjuntamente com os demais Poderes, os limites para a proposta de seu próprio orçamento na Lei de Diretrizes Orçamentárias. Isto porque o constituinte reconheceu também às Defensorias Públicas a mesma autonomia financeira conferida aos demais Poderes e ao Ministério Público, assim como a prerrogativa de propor seu próprio orçamento.

17. Essa equiparaçáo entre a Defensoria Pública e os demais poderes no que diz respeito ao processo legislativo das leis orçamentárias tem sido reforçada pelo constituinte reformador. E $\mathbf{o}$ que se depreende dos arts. 166, $\$$ 14, I [5], e 168 [6] da Constituiçáo Federal, adicionados, respectivamente, pelas Emendas Constitucionais n⿳ 85/2015 e 45/2004.

18. Embora o art. $134, \S 2^{\circ}$, determine a subordinação da prerrogativa conferida à Defensoria Pública de propor seu próprio orçamento ao art. $99, \$ 2^{\circ}$ [7], parece fora de dúvida que se trata de um erro material. A remissáo correta, como corolário da própria autonomia financeira, é ao $\$ 1^{\circ}$ do art. 99.

19. Com efeito, a fixaçáo de limite para a proposta de orçamento a ser enviada pela Defensoria Pública, na Lei de Diretrizes Orçamentárias, náo poderia ser feita sem participaçáo desse órgáo autônomo, conjuntamente com os demais Poderes, como exigido, por extensão, pelo art. 99, $₫ 1^{\circ}$, da Constituiçáo Federal. (Grifou-se)

Lembrando que autonomia orçamentária, segundo Kiyoshi Harada ${ }^{55}$ :

[...] significa que determinado órgão, com ou sem personalidade jurídica própria, foi contemplado pela lei orçamentária anual com dotação própria, fixando o montante das despesas autorizadas, no caso do Judiciário e do Ministério Público, por propostas suas. Autonomia orçamentária quer dizer que um determinado órgão constitui-se em uma unidade orçamentária, podendo utilizar-se das verbas com que foi contemplada, mediante observância dos rígidos princípios orçamentários e à medida de disponibilidade financeira do Tesouro.

Sendo assim, no processo de elaboração da proposta orçamentária global, a Defensoria Pública, tal como o Poder Judiciário e o Ministério Público, detém iniciativa exclusiva de delimitar os recursos necessários para atender às próprias despesas, contando, assim, com a previsão de dotação orçamentária específica.

Essa prerrogativa configura pedra angular da autonomia dessas Instituições e da independência de seus membros, como bem explicita Hugo Nigro Mazzilli ${ }^{56}$, verbis:

[...] Autonomia financeira é a capacidade de elaboraçáo da proposta

\footnotetext{
55 HARADA, Kiyoshi. Autonomia orçamentária. .

56 MAZZILLI, Hugo Nigro. Manual do promotor de justiça, 1991.
} 
orçamentária e de gestão e aplicação dos recursos destinados a prover as atividades e serviços do órgão titular da dotação. Essa autonomia pressupóe a existência de dotaçóes que possam ser livremente administradas, aplicadas e remanejadas pela unidade orçamentária a que foram destinadas. Tal autonomia é inerente aos órgáos funcionalmente independentes, como são o Ministério Público e os Tribunais de Contas, os quais não poderiam realizar plenamente as suas funçôes se ficassem na dependência financeira de outro órgão controlador de suas dotaçôes orçamentárias".

Ora, dotação orçamentária todas as unidades de despesas têm. O Ministério Público, entretanto, mais do que isso, por força da atual Constituição, elaborará sua proposta orçamentária dentro dos limites estabelecidos na lei de diretrizes orçamentárias (CR, arts. 127, $\$$ $3^{\circ}$, e 84 , XXIII), recebendo, em duodécimos, os recursos correspondentes às dotaçôes orçamentárias, inclusive créditos suplementares e especiais (CR, art. 168).

Esta última garantia é complemento necessário da autonomia e da independência funcional. Como anotou, com razão, Eurico de Andrade Azevedo, no parecer acima citado, "é evidente, porém, que essa independência funcional — válida tanto para os seus membros como para a instituição como um todo, é incompatível com interferências externas, submissóes burocráticas e supervisóes orgânicas — só poderá ser exercida eficazmente, só será verdadeira e efetiva se estiver acompanhada de autonomia administrativa e financeira".

Uma vez elaboradas as respectivas propostas orçamentárias, caberá, com exclusividade, ao Poder Executivo, aglutiná-las e encaminhá-las à apreciação do Legislativo, sem, no entanto, exercer qualquer juízo de valoração sobre as mesmas.

Isso porque, caso fosse permitido ao Poder Executivo alterar as propostas encaminhadas pelos demais Poderes e Órgãos, a autonomia financeira destes restaria anulada, pois, ao fazer prevalecer sua vontade sobre os demais, o Executivo poderia reduzir as receitas projetadas como necessárias, a ponto de comprometer as respectivas atividades finalísticas.

Não sem razão, nos autos da ADI 5287, o Supremo Tribunal Federal coibiu a alteração unilateral pelo chefe do Poder Executivo nas propostas orçamentárias apresentadas pela Defensoria Pública em conformidade com a LDO e demais dispositivos constitucionais, por considerar que tal prática configuraria verdadeira violação à separação dos Poderes. Confira-se o excerto do respectivo voto condutor da lavra do Ministro Luiz Fux ${ }^{57}$, verbis:

[...] Porquanto, diante da prerrogativa disposta no $\$ 2^{\circ}$ do art. 134 da CRFB/88, não cabe ao chefe do Poder Executivo, se atendida pela instituição elaboradora da proposta a dupla de requisitos constitucionais mencionada, realizar qualquer juízo de valor sobre o montante ou o impacto financeiro da proposta apresentada. Cabe-lhe tâo somente

57 BRASIL. Supremo Tribunal Federal. Açáo Direta de Inconstitucionalidade (ADI) 5287, Relator(a): Min. LUIZ FUX, Tribunal Pleno, julgado em 18/05/2016, PROCESSO ELETRÔNICO DJe-194 DIVULG 09-09-2016 PUBLIC 12-09-2016. 
consolidar as propostas encaminhadas por essas instituições autônomas e encaminhar a proposta unificada ao órgão legislativo correspondente, sem introduzir nela quaisquer reduçóes ou modificaçóes.

Observe-se que a alteração unilateral pelo chefe do Poder Executivo nas propostas orçamentárias apresentadas pela Defensoria Pública em conformidade com a LDO e com as disposiçôes constitucionais sobre a matéria significaria não apenas uma violação à autonomia constitucional atribuída à referida instituição, mas também à própria cláusula da separação dos Poderes. Isto porque, superada a fase de iniciativa - atribuída, como já dito, ao chefe do Poder Executivo - a apreciação das leis orçamentárias deve se dar perante o órgão legislativo correspondente, ao qual caberá deliberar sobre a proposta apresentada, fazendo-lhe as modificaçóes que julgar necessárias.

Resta, portanto, incontornável o fato de a Defensoria Pública possuir autonomia orçamentária nos mesmos moldes conferidos ao Poder Judiciário e ao Ministério Público, e, por conseguinte, deter orçamento próprio destacado do orçamento fazendário, consoante explicita Emerson Garcia ${ }^{58}$, verbis:

[...] Dotação orçamentária, por evidente, múltiplos órgãos e instituiçóes possuem. Todo feixe de competências existente em um ente estatal, regra geral, necessita de recursos financeiros para bem desempenhar o seu mister. Os Departamentos Penitenciários, os Departamentos de Conservação de Estradas, as múltiplas Secretarias, enfim, todos os órgãos do Poder Executivo são contemplados com dotaçóes orçamentárias. Aqui começa e termina a similitude com o Ministério Público e com os demais Poderes. A justificativa, por sua vez, é tâo simples quanto a conclusão que dela resulta: as dotações dos referidos órgãos derivam de proposta orçamentária elaborada pelo Poder Executivo e são por ele geridas, sendo comum a existência de autorização legislativa específica para o remanejamento de tais dotaçôes de um órgão para outro, sempre ao alvedrio do governante.

As dotaçóes orçamentárias do Ministério Público e dos demais Poderes, ao revés, resultam de proposta orçamentária por eles elaborada e somente eles, por seus respectivos Chefes, podem movimentá-las, o que é consequência direta de sua autonomia financeira.

Do contexto acima destacado, em que a Defensoria Pública é contemplada com dotação orçamentária própria e livre de intervenção do Poder Executivo, tanto no processo de elaboraçáo, quanto na execuçáo dos gastos, eis que só a ela cabe geri-los de acordo com seus interesses e conveniências, extraem-se fundamentos suficientes para derrogar a regra invocada pela Súmula 421/STJ, segundo a qual se extingue a obrigação em decorrência de confusão patrimonial.

E nesse ponto, precisamente, reside o grave equívoco incorrido pela Súmula 421/STJ,

58 GARCIA, Emerson. Ministério Público: organizaçáo, atribuiçóes e regime jurídico. 6. ed. São Paulo: Saraiva, 2017. 
qual seja, conferir uma leitura privatista a um problema de orçamento público, de natureza político-administrativa, para solucioná-lo por meio da confusão.

Conforme mencionamos, a confusão patrimonial é um instituto do Direito Privado, previsto no artigo 381 do Código Civil, cuja definição foi, recentemente, introduzida em nosso ordenamento jurídico através do parágrafo $2^{\circ}$ do artigo 50 do Código Civil, com a redação dada pela Lei ${ }^{\circ} 13.874$, de 20 de setembro de $2019^{59}$, verbis:

Art. 50. [...]

\section{$\$ 2^{\circ}$ Entende-se por confusão patrimonial a ausência de separaçáo de fato entre os patrimônios, caracterizada por:}

I - cumprimento repetitivo pela sociedade de obrigaçóes do sócio ou do administrador ou vice-versa;

II - transferência de ativos ou de passivos sem efetivas contraprestaçóes, exceto os de valor proporcionalmente insignificante; $\mathrm{e}$

III - outros atos de descumprimento da autonomia patrimonial. (Grifo nosso).

A confusão patrimonial guarda pertinência com as relaçóes de natureza consumerista, trabalhista, civilista, comercial, ganhando, outrossim, especial destaque na doutrina da desconsideração da personalidade jurídica, nos termos do artigo 50 do Código Civil suso mencionado.

Por essa razão, revela-se manifestamente indevida a transposição do instituto civilista da confusão patrimonial para a solução de controvérsia específica do Direito Público, qual seja, o orçamento público, que por ser um ato político-administrativo, a espelhar as prioridades eleitas pelo Estado na consecução de seus fins, e possuir normas próprias, inclusive de envergadura constitucional, não pode, a toda evidência, ser equiparado a um conflito de negócio celebrado entre pessoas privadas.

Acerca da particularidade do orçamento público, Luís Roberto Barroso e Eduardo Mendonça $^{60}$ assinalam, verbis:

[...] É inequívoco que a atividade financeira do Estado deve ser minimamente racional e sujeita a controle jurídico e social. Em outras palavras, ninguém defenderá que a arrecadação deva ser aleatória e que os recursos devam ser empregados sem um planejamento que permita equacionar as possibilidades de investimento e as necessidades sociais.

59 BRASIL. Lei $\mathbf{n}^{\circ} \mathbf{1 3 . 8 7 4}$, de 20 de setembro de 2019. Institui a Declaração de Direitos de Liberdade Econômica; estabelece garantias de livre mercado; altera as Leis $\mathrm{n}^{\circ} \mathrm{s}$ 10.406, de 10 de janeiro de 2002 (Código Civil) [...] e dá outras providência.

${ }^{60}$ BARROSO, Luís Roberto; MENDONÇA, Eduardo. O sistema constitucional orçamentário. In: MARTINS, I. G. D. S.; NASCIMENTO, C. V. D.; MENDES, G. F. Tratado de direito financeiro. , 2013. 
Com efeito, atores políticos do Poder Executivo, legisladores, juízes e servidores públicos exercem diferentes graus de influência sobre o conjunto das finanças estatais, obedecem a limites próprios a cada domínio, estabelecem relaçóes diferentes com a opinião pública e dispóem de uma quantidade variável de informaçôes sobre a realidade material. Apesar disso, todos eles interferem nas decisóes orçamentárias concretas, em diferentes níveis. Ao contrário de um orçamento doméstico ou empresarial, que pode seguir uma lógica relativamente linear, as finanças públicas estão sujeitas a interferências vindas de múltiplas direçóes. Isso torna impossível, em termos práticos, a obtenção de uma coordenação perfeita entre os diferentes centros decisórios, mas não desobriga os aplicadores de buscarem a máxima racionalidade possível.

O sistema constitucional das finanças deve ser interpretado e concretizado a partir desse conjunto de ideias. Cabe ao orçamento servir de base para a realização das escolhas democráticas relacionadas à alocação dos recursos.

Sendo assim, a controvérsia específica envolvendo orçamento público, deve ser resolvida tecnicamente como questão orçamentária que é, à luz dos princípios e normas do Direito Público, jamais como um negócio entre pessoas privadas.

De outro giro, apesar de a Defensoria Pública, como todo órgão público, não ser dotada de personalidade jurídica, foi erigida à condição de instituição autônoma e independente dos Poderes Executivo, Legislativo e Judiciário, assim como o Ministério Público, podendo, em razão disso, assumir direitos e contrair obrigaçóes.

De sorte que a ausência de personalidade jurídica, por si só, não configura obstáculo ao recebimento da verba honorária quando a parte é patrocinada pela Defensoria Pública e litiga contra o respectivo ente público.

Cumpre ressaltar que tais verbas não se destinarão a remunerar os Defensores Públicos, mas sim à composição de "fundos geridos pela Defensoria Pública e destinados, exclusivamente, ao aparelhamento da Defensoria Pública e à capacitação profissional de seus membros e servidores", conforme prevê a redação atual do artigo $4^{\circ}$, XXI, da Lei Complementar 80/1994.

Não se olvide que a destinação das verbas sucumbenciais para a ampliação dos serviços prestados e qualificaçáo do respectivo quadro funcional se afigura absolutamente oportuna e necessária ante o cenário deveras conhecido pela sociedade brasileira, assim descrito pela Associação Nacional das Defensoras e Defensores Públicos - ANADEP ${ }^{61}$, verbis:

[...] A Defensoria Pública encontra-se, atualmente, em apenas 40\% das Comarcas brasileiras, sofre com a ausência de repasse de recursos suficientes pelos entes que integram, sendo esses demandados

\footnotetext{
${ }^{61}$ ASSOCIAÇÃO NACIONAL DAS DEFENSORAS E DEFENSORES PÚBLICOS (Brasil). Manifestaçáo da ANADEP sobre recebimento de honorários de sucumbência pela Defensoria Pública é destaque no Blog do Fausto.
} 
pela Instituição por descumprirem direitos e garantias fundamentais de pessoas carentes, que veem diariamente seus direitos a vaga em creche, medicamentos básicos, saneamento básico, à aposentadoria, ignorados, restando à população recorrer ao Poder Judiciário, através da Defensoria Pública, para que tenham o direito de ter direitos efetivamente garantido.

Por todo o exposto, podemos concluir que o óbice da Súmula 421/STJ ao pagamento dos honorários advocatícios à Defensoria Pública quando litiga contra o ente público ao qual se vincula não mais merece subsistir, eis que a Instituição desfruta de ampla autonomia, a qual se equipara à dos demais Poderes e ao Ministério Público - nos termo da ADI 5381 MC retromencionada -, bem como possui dotação orçamentária própria e capacidade de autogestão financeira.

Ademais, o fundamento calcado na confusão patrimonial, instituto do Direito Privado, para solucionar específico problema de orçamento público é manifestamente inadequado, já que as finanças públicas não são equiparáveis a orçamentos domésticos ou empresariais. Trata-se de uma questão orçamentária que como tal deve ser tecnicamente resolvida.

Consequentemente, há que se responder afirmativamente à questão agitada no RE 1.140.005 RG (Tema1002) e estabelecer-se a seguinte tese: a proibição ao recebimento de honorários advocatícios pela Defensoria Pública, quando representa litigante vencedor em demanda ajuizada contra o ente ao qual é vinculada, viola a sua autonomia funcional, administrativa e institucional, sendo, portanto, inconstitucional.

Por derradeiro, considerando o cenário normativo-jurisprudencial, bem como os argumentos retrodelineados, necessário assinalar que a questão constitucional, ora sub judice, não se restringe a uma simples disputa por verbas honorárias sucumbenciais. Trata-se, essencialmente, de uma discussão bem mais delicada e abrangente, qual seja, existência ou não de interesse jurídico-político em conferir efetividade às alteraçóes normativas, constitucionais e infraconstitucionais, já em vigor, que dotaram a Defensoria Pública de elevado e significativo grau de autonomia, em consonância à nobre missão constitucional que lhe fora conferida.

Em outras palavras, o que está posto em xeque, verdadeiramente, é o alcance e a qualidade do serviço público de assistência jurídica integral que se quer proporcionar à sociedade brasileira.

\section{CONSIDERAÇÓES FINAIS}

O presente trabalho se debruçou sobre a questão constitucional suscitada no Leading Case RE 1.140.005 RG (Tema 1002): "saber se a proibição ao recebimento de honorários advocatícios pela Defensoria Pública, quando representa litigante vencedor em demanda ajuizada contra o ente ao qual é vinculada, viola a sua autonomia funcional, administrativa e institucional”. 
Com o intuito de balizar a reflexão, na primeira parte do trabalho, traçamos o status constitucional conferido à Defensoria Pública, a partir da redação original do artigo 134 da Constituição Federal, perpassando pela Emendas Constitucionais no ${ }^{\circ}$. 45/2004, 74/2013 e 80/2014, que, dentre outras inovaçôes, asseguraram à Instituição autonomia funcional e administrativa, bem como a iniciativa de elaborar sua proposta orçamentária, observados os limites legais.

Destacamos, na mesma linha, o relevante papel desempenhado pelo Supremo Tribunal Federal em prol da consolidação da autonomia conferida pelas Emendas Constitucionais retromencionadas, reconhecendo-lhes eficácia plena e a aplicabilidade imediata.

$\mathrm{Na}$ segunda parte, analisamos a disciplina normativa relativa ao pagamento dos honorários advocatícios à Defensoria Pública e, principalmente, o tratamento conferido à matéria pela jurisprudência dos Tribunais Superiores.

Apuramos que, apesar de o artigo 4º, inciso XXI, da Lei Complementar n. 80/1994, com a redação dada pela Lei Complementar n. 132/2009, estabelecer que caberá a Defensoria Pública executar e receber as verbas sucumbenciais decorrentes de sua atuação, inclusive quando devida por quaisquer entes públicos, o Superior Tribunal de Justiça permanece fiel ao entendimento consolidado no verbete da Súmula 421 do próprio Tribunal, segundo o qual não são devidos os honorários advocatícios quando a Defensoria Pública litiga contra o ente federativo ao qual se vincula, em razão da confusão patrimonial entre credor e devedor.

Aduzimos que a jurisprudência majoritária do Superior Tribunal de Justiça, espelhada na Súmula 421/STJ, considera o fato de a Defensoria Pública não possuir personalidade jurídica, de o seu orçamento estar atrelado ao do ente federativo cuja estrutura integra e da confusão patrimonial resultante, como fundamentos suficientes para obstar o pagamento da verba honorária à Defensoria Pública.

No âmbito do Supremo Tribunal Federal, verificamos ter a matéria lá aportado pela primeira vez em 6/11/2008, através do Recurso Extraordinário n. 592.730-0/RS, ocasiáo em que o Tribunal Pleno não reconheceu a repercussão geral do tema.

Não obstante, ressaltamos que, em 9/8/2017, o Plenário da Corte Suprema, dissentindo da própria jurisprudência, ao julgar o Agravo Regimental na Ação Rescisória n. 1.937, admitiu a possibilidade de a Uniâo ser condenada a pagar verbas sucumbenciais à Defensoria Pública, com base, justamente, no reconhecimento da autonomia funcional, administrativa e orçamentária conferida pelas Emendas Constitucionais $\mathrm{n}^{\circ} \mathrm{s}$. 45/2004, 74/2013 e 80/2014. E que essa ruptura na jurisprudência do Supremo Tribunal Federal deu ensejo a que a Corte reconsiderasse o posicionamento anteriormente adotado e reconhecesse a repercussão geral da matéria por ocasião do RE 1.140.005 RG, julgado em 3/8/2018.

Asseveramos que a nova postura adotada pelo Supremo Tribunal Federal reacendeu a esperança de a controvérsia ganhar novo desfecho, agora, de modo favorável à Defensoria Pública. 
$\mathrm{Na}$ última etapa do trabalho, infirmamos os fundamentos esposados pela jurisprudência dominante do Superior Tribunal de Justiça, para o fim de fazer prevalecer os argumentos favoráveis à pretensão da Defensoria Pública.

Para tanto, argumentamos que, diante do elevado grau de autonomia e das relevantes prerrogativas que foram conferidas à Defensoria Pública, é inconcebível considerá-la como um "mero órgáo estadual", tal como mencionado nos julgados que alimentaram a edição da Súmula 421/STJ.

De outro giro, demonstramos a absoluta impropriedade da Súmula 421/STJ ao adotar como fundamento a confusão patrimonial. Primeiro porque desconsidera que a Defensoria Pública, sendo detentora da mesma autonomia orçamentária conferida aos demais Poderes e ao Ministério Público, possui patrimônio próprio, destacado daquele pertencente ao ente público.

Segundo porque a confusão, instituto do Direito Privado, não é adequada para solucionar específico problema de orçamento público, já que as finanças públicas não são equiparáveis a orçamentos domésticos ou empresariais. Trata-se de uma questão orçamentária que como tal deve ser tecnicamente resolvida.

Terceiro porque ignora que a Defensoria Pública, como todo órgão público, apesar de não ser dotada de personalidade jurídica, detém capacidade para assumir direitos e contrair obrigaçóes.

Ressalvamos, oportunamente, que o pagamento da verba honorária não remunerará os Defensores Públicos e será destinada aos "fundos geridos pela Defensoria Pública e destinados, exclusivamente, ao aparelhamento da Defensoria Pública e à capacitação profissional de seus membros e servidores", nos termos do artigo 4\%, inciso XXI, da Lei Complementar 80/1994.

Concluímos que a questão agitada no RE 1.140.005 RG (Tema1002) deve ser respondida afirmativamente, de modo a firmar-se a seguinte tese: a proibiçáo ao recebimento de honorários advocatícios pela Defensoria Pública, quando representa litigante vencedor em demanda ajuizada contra o ente ao qual é vinculada, viola a sua autonomia funcional, administrativa e institucional, sendo, portanto, inconstitucional.

Por derradeiro, aduzimos que as mudanças normativas que conferiram novo status à Defensoria Pública já vigoram há muito tempo, de modo que a questão principal a ser enfrentada pela Corte Suprema não se restringe a uma mera disputa por verbas sucumbenciais. Trata-se, essencialmente, de uma discussão bem mais delicada e abrangente, qual seja, conferir efetividade ou não às normas constitucionais e infraconstitucionais, que alçaram a Instituição à uma posição de destaque no cenário jurídico-político nacional, em reconhecimento ao nobre mister a ela conferido. Portanto, o que está posto em xeque, verdadeiramente, é a qualidade e o alcance do serviço público de assistência jurídica integral que se quer proporcionar à sociedade brasileira. 


\section{REFERÊNCIAS}

ASSOCIAÇÃO NACIONAL DAS DEFENSORAS E DEFENSORES PÚBLICOS (Brasil). Manifestação da ANADEP sobre recebimento de honorários de sucumbência pela Defensoria Pública é destaque no Blog do Fausto. Disponível em: https://anadep.org.br/wtk/pagina/ materia?id=41389. Acesso em: 19/11/2019.

ASSIS, Victor Hugo Siqueira de. Defensoria Pública: Histórico, Afirmação e Novas Perspectivas. Revista da Defensoria Pública da Uniáo, Brasília. n.12, p. 185-209, jan/dez 2019. Disponível em: https://revistadadpu.dpu.def.br/index.php/revistadadpu/issue/view/14 . Acesso em: 25 nov. 2019.

BARROSO, Luís Roberto; MENDONÇA, Eduardo. O sistema constitucional orçamentário. In: MARTINS, I. G. D. S.; NASCIMENTO, C. V. D.; MENDES, G. F. Tratado de direito financeiro. São Paulo: Saraiva, 2013. Volume 1. Livro eletrônico

BRASIL. [Constituição (1988)]. Constituição da República Federativa do Brasil de 1988. Brasília/DF: Presidência da República, [2019]. Disponível em: http://www.planalto.gov.br/ ccivil_03/constituicao/constituicao.htm. Acesso em 25 nov. 2019.

[Constituição (1988)]. Emenda Constitucional n. 45, de 30 de dezembro de 2004. Altera dispositivos dos arts. 5०, 36, 52, 92, 93, 95, 98, 99, 102, 103, 104, 105, 107, 109, 111, 112, 114, 115, 125, 126, 127, 128, 129, 134 e 168 da Constituição Federal, e acrescenta os arts. 103-A, 103B, 111-A e 130-A, e dá outras providências. Disponível em: http://www.planalto.gov. br/ccivil3/constituicao/emendas/emc/emc45.htm. Acesso em 25 nov. 2019.

. [Constituição (1988)]. Emenda Constitucional n. 69, de 29 de março de 2012. Altera os arts. 21, 22 e 48 da Constituição Federal, para transferir da União para o Distrito Federal as atribuiçóes de organizar e manter a Defensoria Pública do Distrito Federal Disponível em: http:// planalto.gov.br/ccivil 03/constituição/Emendas/Emc/emc69. Htm. Acesso em 25 nov. 2019.

[Constituição (1988)]. Emenda Constitucional n. 74, de 6 de agosto de 2013. Altera o art. 134 da Constituição Federal. Disponível em: http://www.planalto.gov.br/ccivil_03/ constituicao/Emendas/Emc/emc74.htm. Acesso em 25 nov. 2019.

. [Constituição (1988)]. Emenda Constitucional n. 80, de 4 de junho de 2014. Altera o art. 134 da Constituição Federal. Disponível em: http://www.planalto.gov.br/ccivil_03/ constituicao/Emendas/Emc/emc80.htm. Acesso em 25 nov. 2019.

. Lei n. 10.406, de 10 de janeiro de 2002. Institui o Código Civil. Disponível em: http:// www.planalto.gov.br/ccivil_03/leis/2002/110406.htm. Acesso em: 25 nov. 2019.

Lei n. 13.105, de 16 de março de 2015. Código de Processo Civil. Disponível em: http://www.planalto.gov.br/ccivil_03/_ato2015-2018/2015/lei/113105.htm. Acesso em: 25 nov. 2019.

. Lei n. 13.874, de 20 de setembro de 2019. Institui a Declaração de Direitos de Liberdade Econômica; estabelece garantias de livre mercado; altera as Leis $\mathrm{n}^{\circ} \mathrm{s}$ 10.406, de 10 de janeiro de 2002 (Código Civil) [...] e dá outras providências. Disponível em: http://www.planalto.gov.br/ ccivil_03/_ato2019-2022/2019/lei/L13874.htm. Acesso em: 25 nov.2019.

. Lei Complementar n. 80, de 12 de janeiro de 1994. Organiza a Defensoria Pública da União, do Distrito Federal e dos Territórios e prescreve normas gerais para sua organizaçáo nos 
Estados, e dá outras providências. Disponível em: http://www.planalto.gov.br/ccivil_03/leis/lcp/ Lcp80.htm. Acesso em: 25 nov. 2019.

Lei Complementar n. 132, de 7 de outubro de 2009. Altera dispositivos da Lei Complementar n80, de 12 de janeiro de 1994, que organiza a Defensoria Pública da União, do Distrito Federal e dos Territórios e prescreve normas gerais para sua organizaçáo nos Estados, e da Lei n-1.060, de 5 de fevereiro de 1950, e dá outras providências. Disponível em: http://www. planalto.gov.br/ccivil_03/leis/lcp/Lcp132.htm. Acesso em: 25 nov. 2019.

Superior Tribunal de Justiça (1. Turma) Recurso Especial (REsp) 541.440/RS, Rel. Ministro José Delgado, 04 de setembro de 2003. DJe em 20 de outubro de 2003, p. 235. Disponível em: https://ww2.stj.jus.br/processo/revista/inteiroteor/?num_registro=200300686944\&dt_ publicacao=20/10/2003. Acesso em: 25 nov. 2019.

Superior Tribunal de Justiça (2. Turma). Recurso Especial (REsp) 1766872/AL, Rel. Ministro Herman Benjamin, 23 de outubro de 2018. DJe em 19 de novembro 2018. Disponível em: https://ww2.stj.jus.br/processo/revista/inteiroteor/?num_registro=201802233999\&dt_ publicacao=19/11/2018. Acesso em 25 nov. 2019.

. Superior Tribunal de Justiça (Corte Especial) Recurso Especial (REsp) 1108013/ RJ, Rel. Ministra Eliana Calmon, 03 de junho de 2009. Dje em 22 de junho 2009. Disponível em: https://ww2.stj.jus.br/processo/revista/inteiroteor/?num_registro=200802779506\&dt_ publicacao=22/06/2009. Acesso em 25 nov. 2019.

. Superior Tribunal de Justiça (Corte Especial). Recurso Especial (REsp) 1199715/RJ, Rel. Ministro Arnaldo Esteves Lima, 16 de fevereiro de 2011. DJe em 12 de abril de 2011. Disponível em : https://ww2.stj.jus.br/processo/revista/inteiroteor/?num_registro=201001218650\&dt_ publicacao=12/04/2011. Acesso em: 25 nov. 2019.

. Superior Tribunal de Justiça (2. Turma). Recurso Especial (REsp) 1786939/AM, Rel. Ministro Herman Benjamin, 21 de março de 2019. DJe em 30 de maio de 2019. Disponível em: https://ww2.stj.jus.br/processo/revista/inteiroteor/?num_registro=201803305339\&dt_ publicacao $=30 / 05 / 2019$. Acesso em:25 nov. 2019 .

. Superior Tribunal de Justiça (1. Turma). Recurso Especial (REsp) 604.977/RS, Rel. Ministro José Delgado, 17 de fevereiro de 2004. DJe em 03 de maio de 2004, p. 123. Disponível em: https://ww2.stj.jus.br/processo/revista/inteiroteor/?num_registro=200302000053\&dt_ publicacao=03/05/2004. Acesso em: 25 nov. 2019.

Superior Tribunal de Justiça (1. Turma). Agravo Interno nos Embargos de Declaraçáo no Recurso Especial (AgInt nos EDcl no REsp) 1529933/CE, Rel. Ministro Benedito Gonçalves, 20 de maio de 2019. DJe em 22 de maio de 2019. Disponível em: https://ww2.stj. jus.br/processo/revista/inteiroteor/?num_registro=201500884054\&dt_publicacao=22/05/2019. Acesso em 25 nov. 2019.

. Superior Tribunal de Justiça (Corte Especial). Embargos de Divergência em Recurso Especial (EREsp) 1192577/RS, Rel. Ministra Laurita Vaz, 21 de outubro de 2015, DJe em 13 de novembro de 2015. Disponível em: https://ww2.stj.jus.br/processo/revista/inteiroteor/?num_ registro=201402469723\&dt_publicacao=13/11/2015. Acesso em 25 nov. 2019.

. Superior Tribunal de Justiça (3. Turma). Agravo Interno no Recurso Especial (AgInt no REsp) 1418091/SP, Rel. Ministro Marco Aurélio Bellizze, 09 de setembro de 2019. DJe em 12 de setembro de 2019. Disponível em: https://ww2.stj.jus.br/processo/revista/inteiroteor/?num_ 
registro=201303715495\&dt_publicacao=12/09/2019. Acesso em 25 nov. 2019.

. Superior Tribunal de Justiça (Corte Especial). Súmula 421. Os honorários advocatícios não são devidos à Defensoria Pública quando ela atua contra a pessoa jurídica de direito público à qual pertença. Julgado em 03 de março de 2010. DJe 11 de março de 2010. Disponível em: https:// scon.stj.br/SCON/sumulas/toc.jsp?livre+421\&b=Sumu\&thesaurus=JURIDICO\&p=true. Acesso em 25 nov. 2019.

. Supremo Tribunal Federal (Tribunal Pleno). Açáo Direta de Inconstitucionalidade (ADI) 5287, Relator Min. Luiz Fux, 18 de maio de 2016. DJe em 12 de setembro de 2016. Disponível em: http://redir.stf.jus.br/paginadorpub/paginador.jsp?docTP=TP\&docID=11638659. Acesso em: 25 nov. 2019.

Supremo Tribunal Federal (Tribunal Pleno). Açáo Direta de Inconstitucionalidade (ADI) 2903, Relator(a): Min. Celso De Mello, 01 de dezembro de 2005, DJe-177 em 19 de setembro de 2008. Disponível em: http://redir.stf.jus.br/paginadorpub/paginador. jsp? docTP=AC\&docID=548579. Acesso em: 25 nov. 2019.

. Supremo Tribunal Federal (Tribunal Pleno). Açáo Direta de Inconstitucionalidade (ADI) 3965, Relatora: Min. Cármen Lúcia, 07 de março de 2012. DJe-065 em 30 de março de 2012. Disponível em: http://redir.stf.jus.br/paginadorpub/paginador.jsp?docTP=TP\&docID=1871030. Acesso em: 25 nov. 2019.

. Supremo Tribunal Federal (Tribunal Pleno). Açáo Direta de Inconstitucionalidade (ADI) 3569, Relator: Min. Sepúlveda Pertence, 02 de abril de 2007, DJe-013 em 11 de maio de 2007. Disponível em: http://redir.stf.jus.br/paginadorpub/paginador.jsp?docTP=AC\&docID=452004. Acesso em: 25 nov. 2019.

. Supremo Tribunal Federal. Repercussáo Geral em Recurso Extraordinário (RE) 592730 RG, Relator: Min. Menezes Direito, 06 de novembro de 2008. DJe-222 em 21 de novembro de 2008. Disponível em http://redir.stf.jus.br/paginadorpub/paginador.jsp?docTP=AC\&docID=564567. Acesso em: 25 nov. 2019.

Supremo Tribunal Federal. Repercussáo Geral em Recurso Extraordinário (RE) 1140005 RG, Relator: Min. Roberto Barroso, 03 de agosto de 2018, DJe-162 em 10 de agosto de 2018. Disponível em: http://redir.stf.jus.br/paginadorpub/paginador. jsp?docTP=TP\&docID=747890405. Acesso em 25 nov. 2019.

Supremo Tribunal Federal (2. Turma). Agravo Regimental no Agravo em Recurso Extraordinário - ARE 1066082 AgR, Relator: Min. DIAS TOFFOLI, 18 de dezembro de 2017. DJe-027 em 14 de fevereiro de 2018. Disponível em http://redir.stf.jus.br/paginadorpub/ paginador.jsp?docTP=TP\&docID=14330578. Acesso em: 25 nov. 2019.

Supremo Tribunal Federal (Tribunal Pleno). Agravo Regimental na açáo Rescisória. AR 1937 AgR, Relator: Min. Gilmar Mendes, 30 de junho de 2017, DJe-175 em 09 de agosto de 2017. Disponível em: http://redir.stf.jus.br/paginadorpub/paginador. jsp?docTP=TP\&docID=13320463. Acesso em: 25 nov. 2019.

- Supremo Tribunal Federal (Tribunal Pleno). Açáo Direta de Inconstitucionalidade (ADI) 5286, Relator: Min. Luiz Fux, Tribunal Pleno, 18 demaio de 2016. DJe-159 em 01 de agosto de 2016. Disponível em: http://redir.stf.jus.br/paginadorpub/paginador. jsp?docTP=TP\&docID=748748019. Acesso em: 25 nov. 2019. 
. Supremo Tribunal Federal (Tribunal Pleno). Açáo Direta de Inconstitucionalidade (ADI) 5381 MC-Ref, Relator: Min. Roberto Barroso, 18 de maio de 2016. DJe-256 em 01 de dezembro de 2016. Disponível em: http://redir.stf.jus.br/paginadorpub/paginador. jsp?docTP=TP\&docID=12140792 . Acesso em 25 nov. 2019.

Supremo Tribunal Federal (Tribunal Pleno). Arguiçáo de Descumprimento de Preceito Fundamental (ADPF) 339, Relator: Min. Luiz Fux, 18 de maio de 2016. DJe-159 em 01 de agosto de 2016. Disponível em: http://redir.stf.jus.br/paginadorpub/paginador. jsp?docTP=TP\&docID=11402259 . Acesso em 25 nov. 2019.

. Supremo Tribunal Federal (Tribunal Pleno). Açáo Direta de Inconstitucionalidade (ADI) 3943, Relatora: Min. Cármen Lúcia, em 07 de maio de 2015. DJe-154 em 06 de agosto de 2015. Disponível em: http://redir.stf.jus.br/paginadorpub/paginador.jsp?docTP=TP\&docID=9058261. Acesso em 25 nov. 2019.

. Supremo Tribunal Federal (Tribunal Pleno). Arguiçáo de Descumprimento de Preceito Fundamental (ADPF) 307 MC, Relator: Min. Dias Toffoli, 19 de dezembro de 2013. DJe060 em 27 de março de 2014. Disponível em: http://redir.stf.jus.br/paginadorpub/paginador. jsp?docTP=TP\&docID=5519916. Acesso em: 25 nov. 2019.

. Supremo Tribunal Federal. Súmula 450. São devidos honorários de advogado sempre que vencedor o beneficiário de justiça gratuita. Sessão Plenária de 01 de outubro de 1964. Disponível em: http://www.stf.jus.br/portal/jurisprudencia/menuSumarioSumulas.asp?sumula=3117. Acesso em: 25 nov. 2019.

ESTEVES, Diogo; SILVA, Franklyn Roger Alves. Princípios Institucionais da Defensoria Pública. 3. ed. Rio de Janeiro: Forense, 2018. Livro eletrônico.

GARCIA, Emerson. Ministério Público: organização, atribuiçóes e regime jurídico. 6. ed. Sáo Paulo: Saraiva, 2017. Livro eletrônico.

GONÇALVES, Carlos Roberto. Direito Civil Brasileiro 2: Teoria Geral das Obrigaçóes. 16. ed. São Paulo: Saraiva, 2019. Livro eletrônico.

HARADA Kiyoshi. Autonomia orçamentária. Disponível em: http://genjuridico.com. br/2019/05/17/autonomia-orcamentaria. Acesso em: 15/11/19.

MAZZILLI, Hugo Nigro. Manual do promotor de justiça. 2. ed., ampl. e atual. São Paulo: Saraiva, 1991. Livro eletrônico.

NERY JÚNIOR, Nelson. Direito constitucional brasileiro: curso completo. 2. ed. São Paulo: Thomson Reuters Brasil, 2019. Livro eletrônico. 